\title{
Tripartite Motif Containing 37 Activates the Wnt/ $\beta$ - catenin Signalling Pathway and Confers Cisplatin Resistance to Ovarian Carcinoma
}

Research

Keywords:

Posted Date: March 3rd, 2021

DOl: https://doi.org/10.21203/rs.3.rs-38330/v2

License: (c) (1) This work is licensed under a Creative Commons Attribution 4.0 International License.

Read Full License 


\section{Abstract}

The authors have requested that this preprint be withdrawn due to erroneous posting.

\section{Full Text}

The authors have withdrawn this preprint from Research Square. 